7. Rubeli A. Paul Hindemiths a Cappella-Werke. Frankfurter Studien: Published by B. Schott's Sohne. Mainz, 1975.

\title{
REFERENCES
}

1. Anisimov, A. (1969) Paul Hindemith. Six Songs on the text of the original French poems by R. Rilke. M.: Music [in Russian].

2. Kisilev, P. (2008). Choral works by Hindemith: Author's thesis.... Extended abstract of candidate's thesis. Moscow, 2008. URL: http://cheloveknauka.com/horovoe-tvorchestvo-hindemita\#ixzz3toRghtf3 [in Russian].

3. Con, Yu., Kholopov, Yu. (1963). On Hindemith's theory. Soviet music, 1963. No.10 [in Russian].

4. Levaya, T., Leontieva, O. (1974). Paul Hindemith. Life and Work. M.: Music [in Russian].

5. Skrebkova-Filatova, M. (1979). On peculiarities of texture development in the chamber choirs by P. Hindemith. Masters of XX century. M.: Sovient composer, 1979. p. 179-209 [in Russian].

6. Ettinger, M. (1967). Harmony in the polyphonic cycles by Hindemith and Shostakovich. Theoretical problems of the music of XX century. M.: Music, Issue 1. p. 441-471 [in Russian].

7. Rubeli, A. (1975). Paul Hindemiths a Cappella-Werke. Frankfurter Studien: Published by B. Schott's Sohne. Mainz [in German].

Стаття надійшла до редакції 22.03.2017

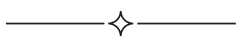

УДК 78.03+78.071.2/78.071.2/.4

Тетяна Олександрівна Федиун

кандидат мистецтвознавства, в.о. доцента кафедри концертмейстерства

Одеської національної музичної

академії імені А. В. Нежданової

tati.fedch@gmail.com

\section{ВПЛИВ ГАСТРОЛЬНО-КОНЦЕРТНОЇ ДІЯЛЬНОСТІ НА СТАНОВЛЕННЯ ФОРТЕПІАННОГО МИСТЕЦТВА ЗАХІДНОУКРАЇНСЬКОГО РЕГІОНУ У ХІХ СТОЛІТТІ}

Мета роботи. Дослідження пов'язане з аналізом гастрольно-концертної діяльності видатних європейських митців та дослідженні їх впливу на формування західноукраїнської фортепіанної традиції, яка завдяки своїм історико-культурним та семантичним особливостям спи- 
рається на специфічно трансформовану західноєвропейську виконавську модель. Методологія дослідження полягає в одночасному застосуванні історико-культурного, музикознавчого аналітичного та виконавського інтерпретаційного підходів. Зазначений методологічний напрям дає змогу розкрити та проаналізувати вплив гастрольно-концертної діяльності європейських митців на формування фортепіанного виконавського мистецтва України. Наукова новизна роботи полягає у висвітленні гастрольно-концертної діяльності представників європейського фортепіанного мистецтва у Західноукраїнському регіоні протягом XIX століття, аналізі впливів індивідуальних здобутків видатних представників європейського мистецтва на формування національної традиції у галузі фортепіанного виконавства та педагогіки. Висновки. Аналіз концертно-виконавських традицій, у тому числі гастрольних виступів визначних європейських та західноукраїнських піаністів у панорамі фортепіанного виконавства регіонального, національного та міжнародного рівня, дає можллвість вийти на певні узагальнення. Професіоналізація концертногастрольної практики ХІХ століття створила підгрунтя для інтенсифікації виступів гастролерів на західноукраїнських землях, що значно розширило представництво різних виконавських традицій.

Ключові слова: західноукраїнська фортепіанна традиція, гастрольно-концертна діяльність, виконавство, фортепіанне виконавство, західноукраїнська фортепіанна школа.

Fedchun Tatiana Alexandrovna, Ph.D. in the History of Art, assistant professor of the concertmastering department, Odessa National A. V. Nezhdanova Academy of Music

The influence of concert tours on the development of the piano art of the Western Ukrainian region in the 19th century

Objective. The research is connected with the analysis of the tour-concert activity of outstanding European figures and the study of their influence on the formation of the Western-Ukrainian piano tradition, which, thanks to its historical, cultural and semantic features, relies on a specifically transformed Western European performing model. The methodology of the study is the simultaneous application of historical, cultural, musicological analytical and executive interpretation approaches. This methodological direction allows us to disclose and analyze the influence of the concert tours of European artists on the formation of the piano performing arts of Ukraine. The scientific novelty of the work is to cover the tour and concert activity of representatives of European piano art in the Western European region during the 19th century, analyze the influence of individual achievements of outstanding European art representatives on the formation of the national tradition in the field of piano performance and pedagogy. Conclusions. The analysis of concert-performing traditions, including tours of outstanding European and Western pianists in the panorama of piano performances of regional, national and international levels, makes it possible to reach 
certain generalizations. The professionalization of the concert-tour practice of the XIX century created the basis for the intensification of the performances of the guest performers in the Western Ukrainian lands, greatly expanded the representation of various performing traditions.

Keywords: West-Ukrainian piano tradition, touring and concert activity, piano performance, West-Ukrainian piano school.

Федиун Татьяна Александровна, кандидат искусствоведения, и.о. доцента кафедры концертмейстерства Одесской национальной музыкальной академии имени А. В. Неждановой

Влияние гастрольного-концертной деятельности на становление фортепианного искусства Западноукраинского региона в XIX веке

Цель работы. Исследование связано с анализом гастрольно-концертной деятельности выдающихся европейских деятелей и исследовании их влияния на формирование западноукраинской фортепианной традиции, которая благодаря своим историко-культурным и семантическим особенностям опирается на специфически трансформированную западноевропейскую исполнительскую модель. Методология исследования заключается в одновременном применении историко-культурного, музыковедческого аналитического и исполнительного интерпретационного подходов. Указанное методологическое направление позволяет раскрыть и проанализировать влияние гастрольно-концертной деятельности европейских художников на формирование фортепианного исполнительского искусства Украины. Научная новизна работы заключается в освещении гастрольно-кониертной деятельности представителей европейского фортепианного искусства в Западноукраинском регионе на протяжении ХІХ века, анализе влияния индивидуальных достижений выдающихся представителей европейского искусства на формирование национальной традиции в области фортепианного исполнительства и педагогики. Выводы. Анализ концертно-исполнительских традиций, в том числе гастрольных выступлений выдающихся европейских и западно-украинских пианистов в панораме фортепианного исполнительства регионального, национального и международного уровня дает возможность выйти на определенные обобщения. Профессионализация концертно-гастрольной практики XIX века создала основу для интенсификации выступлений гастролеров на западноукраинских землях, значительно расширила представительство различных исполнительских традиций.

Ключевые слова: западноукраинская фортепианная традиция, гастрольно-концертная деятельность, фортепианное исполнительство, западноукраинская фортепианная школа.

Актуальність. Формування західноукраїнської фортепіанної традиції нерозривно пов'язане з розвитком концертно-гастрольної діяльності представників видатних європейських піаністичних шкіл. 
Разом з публічними виступами професіоналів-іноземців, що тривалий час пов'язували свою виконавську та педагогічну працю з цими землями, вона формувала смаки слухацької аудиторії, слугувала полем демонстрації методико-педагогічних здобутків національних та авторських шкіл, технічної та інтерпретаційної оснащеності, ознайомлення з репертуарними тенденціями та композиторськими новаціями у галузі піаністичної літератури.

Мета роботи. Дослідження пов'язане з аналізом гастрольно-концертної діяльності видатних європейських митців та дослідженням їх впливу на формування західноукраїнської фортепіанної традиції, яка завдяки своїм історико-культурним та семантичним особливостям спирається на специфічно трансформовану західноєвропейську виконавську модель. Перша половина XIX століття вирізняється нечисленними виступами піаністів-гастролерів, які стають знаковими подіями мистецького життя. Відвідини приїжджих музикантів з концертами відбуваються з приватної ініціативи керівників музичних товариств та провідних місцевих музикантів. До найбільш ранніх спроб централізації концертного життя належить заснування Музичної академії - організації філармонічного типу, польським музикантом Йозефом (Юзефом) Ельснером - в подальшому першим директором Варшавської консерваторії та вчителем Фридерика Шопена. Приїхавши до Львова в 1792 р. (у період високої активності імміграційних процесів), він, крім основних обов'язків директора та диригента львівських театрів, виявив себе як педагог та автор низки фортепіанних композицій. Академія за короткий час функціонування заклала основи централізації зусиль професіоналів та аматорів-меломанів у організованому музикуванні.

Серед найбільш відзначених відгуками преси виступів польських, чеських та австрійських піаністів-гастролерів цього періоду в Галичині - виступ дев'ятилітнього піаніста Юзефа Крогульського (14 березня 1826 року на сцені міського театру), місячний гастрольний тур угорця Ф. Ліста, який охопив Галичину і Буковину (Львів, Станіславів, Чернівці,1847р.), тут концертували також наставник К. Мікулі Ф. Кольберг, С. Бойрер, М. Шимановська, Ф. Чужинська, Й. Клєппш, А. Герцберг, Т. Доелер, Антон, Аполінари і Станіслав Контські, Готліб, Кнапп, Доре, Долежіль, Мілян, Крамер, Келлєрман ${ }^{1}$.

Серед гастролерів особливо важливими є постаті, які своєю діяльністю експонують провідні засади європейської піаністики. До таких,

\footnotetext{
${ }^{1}$ Ініціали низки виконавців як в документах, так і в наукових джерелах відсутні.
} 
безумовно, належить постать Й. Н. Гуммеля. «Гуммель дуже активно концертував як піаніст, з успіхом виступав на всіх основних сценах Європи - від Англії до Росії, найбільше виконував твори В. А. Моцарта та власні. В 1822 р. - найімовірніше на запрошення свого колишнього учня Франца Ксавера Моцарта, що вже майже п'ятнадцять років перебував в столиці Галичини - виступав також із клавірабендом у Львові, про що залишились згадки в пресі» [10; 14].

Ще будучи за кордоном на навчанні, почав приїжджати до Львова як концертуючий музикант, який здобув музичну освіту у Відні та Парижі, учень Я. Н. Гуммеля - Й. Рукгабер. Зокрема в двадцятих роках XIX сторіччя виступав у Львові як піаніст-соліст та камераліст в ансамблі з польським скрипалем Каролем Ліпінським.

Поряд з приїзжими виконавцями активністю публічного концертування вирізняються місцеві освічені концертуючі піаністи-аматори Львова: учениця Ф. К. Моцарта баронеса Юлія Бароні-Кавалькабо, С. Дульська, Г. Лончиньська. Знаменим з історичної точки зору $є$ виконавський дебют у Львові Теодора Лєшетицького - видатного піаніста-виконавця та педагога-методиста, чиї мистецькі засади надалі стануть одними з найбільш широко представлених на західноукраїнських територіях у другій половині XIX - на поч. XX століття. «...Найвидатнішим фортепіанним педагогом Відня наприкінці XIX ст. став не будь-хто з лістіанців, а учень Черні - Теодор Лєшетицький. Теодор Лєшетицький (Leschetizky, 1830-1915) був сином чеського музиканта, народився в Галичині. Свій перший концерт він, маючи 9 років, дав у Львові під керівництвом Фр. К. Моцарта, а систематичну концертну кар'єру дорослого музиканта розпочав у Відні 1840-х рр.» [3, 60].

Особливої уваги заслуговує місце у становленні фортепіанної традиції цього періоду австрійського музиканта-універсала Й. К. Кеслєра Аналізуючи характер і спрямованість його діяльності, приходимо до висновку, що вона є компонентом складного синтетичного комплексу, який творить галицька музична культура завдяки привнесенням, здійсненим Й. Рукгабером, Ф. К. Моцартом, Й. Башни, К. Мікулі, К. Ліпінським, І. Шупанцігом, Й. Медеріч-Галлюсом та ін., завдяки тривалим періодам праці у якості педагогів, виконавців, диригентів, учасників камерних та оркестрових колективів, композиторів, учасників та організаторів мистецького життя. Європейський досвід, привнесений у ці сфери життя краю, збагатив його надбаннями і напрацюваннями різних національних культур. На цьому тлі 
постать К. Й. Кеслєра постає як одна з провідних у плеяді визначних тогочасних музикантів Свропи.

Й. К. Кеслєр нерідко брав участь у благодійних акціях. У львівський період діяльності став активним членом Галицького товариства шанувальників музики (яке тоді іменувалося «Galizischer Musikverein»), а згодом - членом його дирекції. У 1859 р., вже після від'їду музиканта до Відня, його було обрано почесним членом товариства, що змінило назву на Галицьке музичне товариство (у період 1858-1919 pр. воно називалось «Galicyjskie Towarzystwo Muzyczne», надалі - ГМТ) [9, 40-46].

У 1840 р. Й. К. Кеслєр подарував Товариству ГМТ партитуру ораторії «Створення світу» Й. Гайдна німецькою та англійською мовами [12], яка тривалий час була у репертуарі концертних програм мистецького об'єднання. У 1855 р. мистець залишив Львів, продиригувавши доброчинним концертом на користь євангельської громади у редутовому залі графа Скарбка [13].

Австрійський мистець, усвідомлюючи потреби професіоналізації концертного життя, постав диригентом, камералістом, акомпаніатором, солістом, наставником молодого покоління концертуючих піаністів, серед яких збереглися імена Олександра Зарицького, С. Дунєцкої та ін.

Як член правління ГМТ Й. К. Кеслєр долучився до урочистої зустрічі Ф. Ліста, взявши участь у підготовці й організації виконання привітальних кантат (імовірно авторства Й. Рукгабера) на його честь.

Гастрольні виступи Ференца Ліста на землях Західної України мали особливе значення, вирізняючись географічним масштабом охоплених осередків, значимістю концертних акцій, впливом на процеси поширення лістівських принципів концертного виконавства та зацікавлення його педагогічною системою. Видатний угорський композитор Ф. Ліст провів у Львові один з місяців гастрольного туру 1847 року, прийнявши запрошення директора Галицького музичного товариства композитора й піаніста Й. Рукгабера. Його концертні виступи відбулись у трьох залах: у залі Галицького музичного товариства $(17,20,26$ квітня); у благодійному концерті в театрі графа Скарбка, що став найбільш масовою мистецькою подією цього туру (2 травня), та в залі бібліотеки наукового закладу Оссолінських (27 квітня). Окрім сольних програм він виступив в дуеті з піаністкою Софією Борер, скрипалем і композитором Феліксом Ліпінським (братом знаменитого Кароля Ліпінського), виконав концерти 
К. М. Вебера для фортепіано з оркестром та продиригував Великою симфонією (Симфонією № 5) Л. Бетховена. У його програмах прозвучали твори, транскрипції і парафрази В. Белліні, Л. Бетховена, К. М. Вебера, А. В’єтана, Г. Доніцетті, В. А. Моцарта, Дж. Россіні, Ф. Шопена, Ф. Шуберта, Ф. Ліпінського, львівського композитора Й. К. Кеслєра та власні оригінальні опуси. Беручи до уваги вагомість програм та «геніальний артистизм» виконання, який відзначала преса $[5,191]$, очевидним $є$ шанобливе трактування угорським музикантом опусів львівського композитора ${ }^{1}$.

Ф. Ліст подарував хорові ГМТ у Львові партитуру чотириголосного чоловічого хору «Reiterlied» («Пісня вершника») з посвятою, а згодом під враженням подорожі Галичиною оркестрував «Галицькі танці» сюїту для фортепіано в 4 руки житомирського композитора Юліуша Зарембського куди, зокрема, увійшли українські народні пісні «Гандзя», «Добрий вечір, дівчино, куди йдеш» (твір віднайдено у 1996 р. в приватній колекції у Брюсселі) [1, 209-216; 4, 119-124; 5, 189-195].

Серед постатей, які принципово формували характер концертної практики в Галичині та Буковині, був чеський музикант, виходець 3 музичної буковинської родини Л. Марек, який на початку 1870-х років оселився у Львові та, будучи переконаним лістіанцем, виявив себе як яскравий і самобутній інтерпретатор та організатор мистецького життя.

Глибоко сприйнявши віртуозно-концертну манеру лістівської інтерпретації та принципи фортепіанної педагогіки вже у зрілому віці, Л. Марек надалі зберіг їм вірність, на противагу нюансово-психологічній духовній роботі, зумовленій слідуванням шопенівським засадам, перейнятим від К. Мікулі та його послідовників. Однак близькою Ф. Лісту була і його суспільна позиція - активна організаційна діяльність (праця артистичного директора Музичного товариства чоловічого співу «Гармонія», ведення школи гри на духових інструментах з метою укомплектування повноцінного оркестрового складу, формування школи фортепіанної гри як осередку лістіанської традиції в Галичині, із залученням до співпраці передових викладацьких сил), освітньовиховний характер програм, популяризація кращих зразків світової класики (насамперед творів Л. Бетховена та Ф. Ліста), безпосередня

\footnotetext{
1 Зауважмо, твори Й. К. Кеслєра зустрічалися в репертуарі молодого угорського композитора від його перших паризьких гастролей у 1820-ті роки, у програмах зібрних концертів, що складалися для аристократичних салонів за платними рекомендаціями Дж. Россіні, відповідального за їх склад і дотримання [2, 11]
} 
участь у формуванні регіональної традиції камерного музикування та концертно-гастрольного життя, створення різножанрових музичних композицій, орієнтованих на реальний виконавський потенціал.

На підставі польськомовної періодики Л. Мазепа дослідив сталу участь піаніста у концертах камерної музики львівських аристократів та знатних міщан, що влаштовувалися в домах родини Шимоновичів, графа Бароні, Адама-Войцєха Цибульського, графів Леопольда та Юзефа Стаженьських (які були відмінними скрипалями-камералістами) та ін., у яких були задіяні професійні музиканти і освічені аматори зі Львова (К. Мікулі, Л. Марек, Лапчиньський, Ернесті, Гебельт, Пляйнерт) та виконавці-гастролери (Г. та Ю. Вєнявські, Н. Бєрнацький) $[9,36]$.

Його велика заслуга полягала й у тому, що він постійно підтримував контакти з відомими зарубіжними музикантами, завдяки чому львівські слухачі почули таких видатних піаністів, як К. Таузіг, Г. фон Бюлов, А. Рубінштейн, а також А. Барбі, В. Мєржвінський, Люкка та багатьох уславлених співаків. Його вілла стала осередком активного артистичного життя [6, 43-46; 8, 25-26].

Гастрольна діяльність запрошених піаністів-виконавців мала важливе значення для формування смаків і вподобань освіченої і підготованої аудиторії, окрім того особисті мистецькі контакти нерідко мали вплив на подальшу долю піаністів-початківців. Так, наприклад, на вибір педагога для М. Розенталя мав вплив демарш К. Мікулі та його 30 учнів під час виступу Г. фон Бюлова у Львові в театрі графа Скрабке (запрошеного його конкурентом Л. Мареком). Інший гастролер Р. Джозефі - учень Ф. Ліста, прослухавши гру цього вундеркінда, запросив його на навчання до Відня. Після спільного концерту К. Мікулі (соло та у складі оргаінзованого ним тріо, яке давало щотижневі концерти у великому залі львівської Ратуші) та 13-річного М. Розенталя під час фестивалю А. Міцкевича Галицький сейм виділив молодому музикантові щорічну стипендію для вдосконалення його майстерності у розмірі 300 гульденів.

Після гастрольної подорожі містами Росії, Польщі, Угорщини, Румунії виступ Л. Марека у Львові у якості соліста відбувся у 1854 р. в програмі концерту ГМТ, у якому було виконано Фантазію для фортепіано Е. Прудента на теми опери «Лючія ді Ляммермур» Г. Доніцетті (Fantasia on Donizetti's «Lucia di Lammermoor») Op. 8 [9, 49].

У 1872 р. піаніст їде до Ваймара, щоби навчатися у Ф. Ліста, успішно концертуючи в Німеччині та Австрії у 1872-1873 pp. В 1873 році пі- 
аніст під час тривалого концертного турне блискуче виступив у Відні. 3 цього часу композиції наставника (насамперед рапсодії і парафрази) стали постійною складовою його репертуару. Згодом в австрійській столиці Л. Марек брав уроки з аналізу музичних форм у Ганса фон Бюлова, завдяки чому добре опанував класичну музику і, зокрема, твори Л. Бетховена. Це принесло йому в майбутньому славу одного з найкращих виконавців фортепіанної спадщини цього композитора.

В подальшому, у 1870-ті pр. музичне життя Львова, концертні виступи та музична освіта знаходились під впливом різкого протистояння шопенівських виконавсько-педагогічних традицій, які послідовно впроваджував та пропагував К. Мікулі, принципам ефектно-віртуозної стилістики Ф. Ліста (в особі Л. Марека - учня К. Мікулі та Ф. Ліста, блискучого виконавця та засновника фортепіанної музичної школи). В майбутньому серед учнів визначного піаніста і викладача першу лінію продовжили Р. Шварц, В. Вшелячинський, С. Нев'ядомський, $Ф$. Нейгаузер, альтернативну - Л. Марек та М. Розенталь. Це протистояння знайшло відображення у тогочасній мистецькій періодиці як війна партій «маркістів» і «мікулістів».

У 14 років він дебютує у Відні, виконуючи Другий концерт Ф. Шопена з Р. Джозефі, варіації Л. Бетховена до мінор, Кампанеллу Ф. Ліста. В цей період гастролює по Румунії настільки успішно, що стає піаністом Румунської королівської сім'ї (у 1902 р. був нагороджений найвищим орденом цієї країни, отримави відзнаку з рук короля). У жовтні 1876 р. Відень відвідує Ференц Ліст, який, почувши гру М. Розенталя, прийняв його в число своїх учнів. В період навчання у Ліста молодий піаніст виступає в Санкт-Петербурзі, Варшаві, Парижі та інших містах. Виконавець підтримував дружні стосунки з Й. Брамсом, Р. Штраусом, А. Рубінштейном, Г. фон Бюловим, К. Сен-Сансом, Ж. Массне та І. Альбенісом. У 1906 р. Президент США Теодор Рузвельт прийняв Розенталя в Білому Домі. У 1912 р. австрійський імператор Франц Йосиф I нагородив свого підданого титулом «Піаніст імператорського двору». Розенталь виступав перед королем Іспанії. Однак найпам'ятнішим для нього залишився виступ перед російським царем Олександром II в Бухаресті.

У Відні в 1927 р. М. Розенталь не зміг відвідати бенефіс Марцеліни Сембріх, з якою разом відвідував уроки теорії, гармонії у професора Франтішека Сломковського та фортепіано у К. Мікулі. Наприкінці 1930-х рр. піаніст виступав разом з диригентом Нью-Йоркської філармонії Артуром Родзінським (колишній диригентом Львівської опери). 
Дбаючи про активність та різноманітність мистецького життя, міський і крайовий президент Буковини Карл Ріттер Умлауф фон Франквелл запрошував сюди фахових виконавців зі Львова - Франца Кольберга, Леопольда фон Майєра, Ігнасія Тедеско, що виступали у маєтках місцевих магнатів. 3 його ініціативи місто відвідав Ф. Ліст. Великий вплив на розвиток фортепіанної традиції краю мали гастролі угорського піаніста, який прибув сюди у травні 1847 р. зі Львова через Станіславів на запрошення президента К. Р. Умлауфа. Саме Буковина стала наступним після Галичини регіоном гастрольного туру видатного піаніста 1847 року (виступи угорського музиканта відбулися 29-30 квітня (12-13 травня) ${ }^{1}$ у Чернівцях). Це були два концерти в готелі «Молдавія», власником якого був батько Кароля Мікулі - купець Якоб фон Мікулі (тогочасна назва - «Під чорним орлом» - в найстаршому будинку № 7 Центральної площі, тепер тут розташовуються приміщення торговельно-економічного інституту). В його великому залі відбулися два публічні концерти угорського музиканта (частину коштів з яких виконавець передав для знедолених дітей) та один - в палаці барона Євдоксія Гормузаті, приватні концерти в домі адвоката Загорського, маєтку барона Й. фон Мустяци. Буковинські слухачі мали можливість почути у виконанні Ф. Ліста власні композиції - одну з «Угорських рапсодій», «Поховальний похід» (пам’яті повстання ліонських ткачів) та «Кампанеллу» 3 циклу «Великі етюди за Паганіні (Grandes études de Paganini)»² [11], транскрипції увертюри до «Вільгельма Телля» Дж. Россіні та «Лісового царя» Ф. Шуберта, парафраз на оперу В. А. Моцарта «Дон-Жуан», «Місячну сонату» Л. Бетховена, низку композицій Ф. Шопена (полонез Es-dur, вальси, мазурки) i, традиційно, імпровізацію на місцеву тему - коломийку та низку імпровізацій на прохання публіки.

Третій концертний виступ угорського піаніста відбувся в палаці барона Гормузакі. У домі останнього гостеві було запроновано послухати гру талановитого народного циганського скрипаля-мошула Ніколє Піку з Сучави (Миколи Сачавського), оскільки мистець досліджував музику угорських циган. Велике враження на Ф. Ліста справила гра народного музиканта-скрипаля Алеко Цурцумана, почута після публічного виступу в маєтку одного з місцевих аристо-

\footnotetext{
${ }^{1}$ Вольська подає 11 (23) травня датою виїзду в Ясси.

${ }^{2}$ Нагадаємо, що цикл було опубліковано у в 1851 році. Цикл є переглядом складнішої версії 1837 року, що була опублікована під назвою «Етюди трансцендентної складності за Паганіні» (Études d'exécution transcendante d'après Paganini).
} 
кратів у с. Глинниця. Занотовані мелодії Ф. Ліст згодом використав у своїх угорських рапсодіях (зокрема «Забавний танець») [7, 23-25]. Невдовзі у місті концертувала учениця Ф. Ліста - Софія Бойрер.

3 виїздом К. Умлауфа з Буковини (1850р.) стан концертування різко знижується незважаючи на періодичні спроби місцевих діячів (в т. ч. піаніста К. Кьоніга) відновити перервану традицію і заохотити до опанування інструменту.

Закладення (травень 1876 р.) і відкриття власного концертного залу (грудень 1877 р.) «Музичного товариства» у Чернівцях, до 20-ліття організації (1882) знаменувалося участю в програмі урочистостей К. Мiкулі (й інших представників педагогічного складу консерваторії Галицького музичного товариства у Львові) та виконанням його творів.

У 1879 р. на запрошення відомого музичного діяча, чеха Адальберта (Войтеха) Гржімалі ${ }^{1}$ (1842-1908) керівника «Товариства плекання музичного мистецтва на Буковині» до Чернівців приїхав російський піаніст, композитор та диригент Антон Рубінштейн (виступ відбувся 18 січня в будинку Товариства), в програмі якого прозвучали: увертюра «Егмонт» Л. Бетховена, «Рондо» В. А. Моцарта, Арія та варіації Г. Ф. Генделя, Ноктюрн та Варіації Ф. Шопена, композиції Р. Шумана та Ф. Ліста і власні композиції - Баркарола та етюди. Зауважимо, що з творчістю А. Рубінштейна буковинські шанувальники музичного мистецтва познайомилися раніше. В одній з концертних програм Товариства у 1878 році тут прозвучав і «Вальс-каприс», який композитор присвятив героям російсько-турецької війни 1877-1878 pp.

Серед гастрольних виступів угорських піаністів на територіях Західноукраїнського регіону особливе місце належить Закарпаттю. Так, Ф. Ліст неодноразово відвідував Мукачеве ${ }^{2}$, Ужгород (виступав тут в ресторані «Золота корона») та Великі Лази ${ }^{3}$ у зв'язку з дружніми стосунками з Нандором Плотені, де виступав в концертних програмах та салонних вечорах соло та в дуеті з господарем (до 1867 р). Нагадаємо,

${ }^{1}$ До приїзду в Чернівці він працював диригентом симфонічних оркестрів.у Роттердамі (Голандія) і Гетенбурзі (Швеція), згодом повернувся на батьківщину, де спочатку очолив симфонічний оркестр чеського Національного театру, потім був другим диригентом німецького театру в Празі.

${ }^{2}$ Ф. Ліст з Міхаєм Мункачі - главою угорської реалістичної школи живопису, діячем з Мукачевого. Останньому належить полотно «Портрет Ференца Ліста», натомість композитор присвятив живописцеві свою 16-ту «Угорську рапсодію» [4, 123].

${ }^{3} 23$ грудня 2011 р. у с. Великі Лази Ужгородського району перед палацом графа Нандора Плотені встановлено пам'ятник Ференцу Лісту. Автор пам'ятника - закарпатський скульптор Михайло Белень, відомий роботами з угорської тематики. 
що з цим музичним діячем пов'язані також концертні виступи дуету Е. Ременьї та Й. Брамса у містах регіону.

Висновки. Аналіз концертно-виконавських традицій (гастрольні виступи визначних європейських та західноукраїнських піаністів у панорамі фортепіанного виконавства регіонального, національного та міжнародного рівня) дає можливість вийти на певні узагальнення. Підсумовуючи вищесказане, підкреслимо, що XIX століття характеризується усталенням низки новаторських форм фортепіанного концертування. Якщо в польському середовищі поряд зі збірними програмами практикувалися сольні фортепіанні концерти, то нормою вони стають лише з закоріненням цієї традиції у практиці українських піаністів. Важливим засобом формування мистецьких запитів аудиторії та проявом патріотичної громадянської позиції були концертні виступи виконавців регіону, які вже здобули широке визнання у країнах Європи та на інших континентах. Їх програми демонструють високий технічних рівень та серйозні інтерпретаторські завдання, несуть потужний виховний та естетичний потенціал, спрямовуючи слухача на глибоке і вдумливе сприйняття багатого різностильового репертуару.

Подальша професіоналізація концертно-гастрольної практики в кінці XIX століття створила підгрунтя для інтенсифікації виступів гастролерів на західноукраїнських землях, що значно розширило представництво різних виконавських традицій. Зокрема у Львові з цією метою в 1892 році було створене концертне бюро ГМТ, яке взяло на себе забезпечення адміністративних проблем організації концертів у місті. За період 1882-1900 рр. за його допомогою було запрошено таких виконавців як Е. Шеллінг (1883р.), А. Рубінштейн (1879р.), Г. фон Бюлов (1872, 1887 рр.), О. Міхаловські (1879 та 1899 р.), Е. д’Альбер (ряд програм у 1886-1888 pр.), І. Падеревський (1887 р.), А. Грінфельд (1887 р.), Е. Зауер (1893 р.). В 1880 р. у Львові відбулися спільні виступи Йоганнеса Брамса та Йожефа Йоахіма [6, 17]. Вищенаведені приклади свідчать про інтенсивність змін самих засад і цілей концертної діяльності, принципів концертування, збагачення їх новітнім репертуаром, спрямуванням на ії просвітницький характер, послідовну популяризацію національної та регіональної фортепіанної творчості, збагачення репертуару, що принципово змінює співвідношенням між виконавцем та цільовою аудиторією. 


\section{СПИСОК ЛІТЕРАТУРИ}

1. Антонюк I. 3 історії музичних колекцій бібліотеки Львівської державної музичної академії ім. М. В. Лисенка. Вісник Львів. ун-ту. Серія Книгознавство. Львів : ЛНДУ ім. І. Франка, 2007. Вип. 2. С. 209-216.

2. Будяковский А. Пианистическая деятельность Листа. Л.: Музыка, 1986.88 с.

3. Дітчук О. Фортепіанна культура Відня та зв'язки з нею української піаністики. Вісник Львівського університету. Львів: ДНУ, 2008. Вип. 8. С. 55-69.

4. Драган М. Вплив концертно-виконавської та педагогічної діяльності Ференца Ліста на українське фортепіанне мистецтво. Наукові записки Тернопільського національного педагогічного університету ім. В. Гнатюка. Тернопіль, 2011. № 1. С.119-124.

5. Колбін Д. Виступи Ференца Ліста у Львові. Musica Galiciana. Л., 1999. Т. 3. С. $189-195$.

6. Куржева Т. Польські піаністи у Львові наприкінці XIX - початку XX століття : дослідження. Львів : СПОЛОМ, 2005. 116 с.

7. Кушніренко А., Залуцький О., Вишпінська Я. Історія музичної культури і освіти Буковини : навч. посібник. Чернівці : ЧНУ, 2011. 376 с.

8. Лабанців-Попко 3. Сто піаністів Галичини. Львів : НТШ, 2008. 224 с.

9. Мазепа Л., Мазепа Т. Шлях до музичної Академії у Львові. Львів : СПОЛОМ, 2003. Т. $1.288 \mathrm{c.}$

10. Ткачик М. Камерно-інструментльна творчість Йогання Рукгабера. Музичне мистецтво : зб. наук статей. Донецьк ; Львів : Юго-Восток, 2009. № 9. C. $18-27$.

11. Шукаючи Ліста. Доба. 2007. № 24 (552), 14 червня.

12. Gazeta Lwowska. 1840. № 34, № 71.

13. Nowiny. 1955. № 38.

14. Wiener Klavierschule. Österreichische Musiklexikon. Wien, 2003. C. 10611064 .

\section{REFERENCES}

1. Antonyuk I. From the history of musical collections of the library of the Lviv State Musical Academy named after. MV Lysenko // Visnyk Lviv. un-th Series of book science. Lviv: LNDU them. I. Franco, 2007. Proceedings. 2. [in Ukrainian]

2. Budyakovsky A. Pianist activity of the letter. L.: Music, 1986. [in Ukrainian]

3. Ditchuk O. The Piano Culture of Vienna and its links with Ukrainian pianotics // Visnyk of Lviv University. Lviv: DNU, 2008. Vp. 8. [in Ukrainian]

4. Dragan M. Impact of Ferenc Liszt Concert Performing and Pedagogical Activity on Ukrainian Piano Art // Scientific Notes of the Ternopil National Pedagogical University named after. V. Hnatyuk. Ternopil, 2011. No. 1. [in Ukrainian]

5. Kolbin D. Performances of Ferenc Liszt in Lviv // Musica Galiciana. L., 1999. T. 3. [in Ukrainian]

6. Kurzheva T. Polish pianists in Lviv in the late nineteenth and early twentieth centuries: research. Lviv: SPOLOM, 2005. [in Ukrainian] 
7. Kushnirenko A., Zalutsky O., Vyshpinskaya Y. History of Music Culture and Education of Bukovina: Teach. manual. Chernivtsi: ChNU, 2011. [in Ukrainian]

8. Labans-Popko S. One hundred Halychyna pianists. Lviv: NTSh, 2008. [in Ukrainian]

9. Mazepa L., Mazepa T. Path to the Musical Academy in Lviv. Lviv: SPOLOM, 2003. T. 1. [in Ukrainian]

10. Tkachyk M. Chamber-instrumental creativity of Jogany Rukgaber // Musical art: Sb. science articles. Donetsk-Lviv: Southeast, 2009. No. 9. [in Ukrainian]

11. Looking for Liszt // The Day. 2007. No. 24 (552). June 14th. [in Ukrainian]

12. Gazeta Lwowska. 1840. № 34, № 71. [in Polish]

13. Nowiny. 1955. № 38. [in Polish]

14. Wiener Klavierschule // Österreichische Musiklexikon. Wien, 2003. [in German]

Стаття надійщла до редакції 01.03.2017

УДК 78.03+787.6/.7

\section{Валентина Петрівна Кириченко}

заслужена артистка України, доцент кафедри народних інструментів Одеської національної музичної академії ім. А. В. Нежданової

kyrychenko.valentyna@gmail.com

\section{ДЖАЗОВІ ТВОРИ В. ВЛАСОВА ДЛЯ ДОМРИ}

Мета роботи. У статті визначається джазова стилістика у сучасному домровому виконавстві на прикладі оригінальних творів для домри В. Власова «Джеаз-кониертіно», «Бассо-остинато». Методологія дослідження полягає в застосуванні компаративного, естетико-культурологічного, історичного методів, а також музикознавчого та виконавського аналітичних підходів, які утворюють єдину методологічну основу. Зазначений методологічний підхід дозволяє розкрити виконавську модель джазових творів для домри. Наукова новизна роботи полягає в розширенні уявлень про сучасний домровий репертуар за рахунок введення актуальних джазових стилістичних засобів. Визначається специфіка оволодіння домристом джазовою манерою гри, зокрема особливостями синкопування, «тернарного» принципу ритмічних пропориій, переважсання домрового прийому «деташе», використання glissando та гри з підтягуванням, втілення «духу» джазової імпровізаційності та свободи. Висновки. Категорії колективності, гри, цілісності, а також дитинства, дитячості виступають у дитячому фольклорі (поряд з синкретизмом, утилітарністю, символізмом, образністю, декоративністю і традиційністю) тими осно-

(C) Кириченко В. П., 2017 